\title{
Conversas de lotação: política, cidade e cotidiano nas crônicas cariocas de José Lins do Rego (1944-1956)
}

\author{
Bernardo Borges Buarque de Hollanda ${ }^{1 *}$ \\ ${ }^{1}$ Fundação Getúlio Vargas, Rio de Janeiro/RJ - Brasil
}

Regiane Matos ${ }^{2 * *}$

${ }^{2}$ Pontifícia Universidade Católica do Rio de Janeiro, Rio de Janeiro/RJ - Brasil

\section{RESUMO}

O presente artigo argumenta que uma série inédita de crônicas de autoria de José Lins do Rego (1901-1957) contribui para compreender importantes aspectos da vida social e política do Rio de Janeiro, então capital da República, durante as décadas de 1940 e 1950 . Os milhares de microtextos publicados pelo romancista nordestino no jornal $O$ Globo, em coluna intitulada Conversa de lotação, nunca lançados em livro pelo escritor, revelam o cotidiano do Distrito Federal sob a ótica intersubjetiva de seus habitantes. A base para tanto são as interaçôes diárias do cronista com os passageiros de um meio de transporte coletivo, característico da cidade em meados do século XX, em seu translado da Zona Sul para o Centro da cidade. A seleção de artigos aqui reproduzida procura ser uma amostra das questóes debatidas nessa espécie de espaço público transitório, o veículo lotação, por intermédio de seus cidadáos-passageiros. Para efeito de recorte de uma produção bastante extensa, enfocamos dois ângulos principais: de um lado, o debate nacional em torno das eleiçóes para a presidência da República, em outubro de 1950; de outro, os problemas de âmbito municipal, relativos ao crescimento urbano da cidade no princípio daquele decênio, a partir dos relatos capturados pela crônica de Lins do Rego, acerca dos engarrafamentos e de outros transtornos vivenciados pela populaçáo no dia a dia da cidade do Rio de Janeiro.

Palavras-chave: crônica; Rio de Janeiro; política; José Lins do Rego; história.

DOI: http://dx.doi.org/10.1590/2237-101X02104311.

Artigo recebido em 19 de junho de 2018 e aceito para publicação em 4 de dezembro de 2018.

* Professor da Fundaçáo Getúlio Vargas / Escola de Ciências Sociais, Rio de Janeiro/RJ - Brasil. E-mail: bernardobuarque@gmail.com. ORCID: https://orcid.org/0000-0001-7781-4684.

** Doutoranda do Programa de Pós-Graduação em História Política e Bens Culturais / CPDOC / Fundação Getúlio Vargas e atualmente bolsista CAPES Print na École des Hautes Études en Sciences Sociales (EHESS, Paris). E-mail: regianematos89@gmail.com. ORCID: https://orcid.org/0000-0003-3169-1978. 


\section{Conversations on a bus: politics, city, and daily life in José Lins do Rego's crônicas of Rio de Janeiro city}

\section{ABSTRACT}

This article argues that an unpublished series of crônicas (short writings) written by José Lins do Rego (1901-1957) can contribute to the understanding of important aspects of the social and political life of Rio de Janeiro during the 1940s and 1950s, then capital of the Republic. Thousands of short writings published by the northeastern novelist in the newspaper $O$ Globo, in a column titled Conversa de lotação (Bus conversations), which were never published in a book by the author, reveal the daily life of the Federal District under the intersubjective view of its inhabitants. The basis for such are the writer's daily interactions with the passengers of a collective means of transport, which were characteristic of the city in the mid-twentieth century, in his commute from the southern part of the city to downtown. The selection of articles reproduced here seeks to be a sample of the issues debated in this kind of transient public space, the bus, by its citizen-passengers. In order to set analytical marks on a rather extensive production, we focus on two main angles: on the one hand, the national debate surrounding the presidential elections in October 1950; on the other, the municipal problems related to the urban growth of the city in the beginning of that decade, based on the reports captured by the short writings of Lins do Rego about the traffic jams and other disorders experienced by the population in the daily life of the city of Rio de Janeiro.

Keywords: short writings; Rio de Janeiro; politics; José Lins do Rego; history.

\section{Conversa de autobús: Política, ciudad y cotidiano en las crónicas cariocas de José Lins do Rego (1944-1956)}

\section{RESUMEN}

El presente artículo argumenta que una serie inédita de crónicas de autoría de José Lins do Rego (1901-1957) contribuye para comprender importantes aspectos de la vida social y política de Río de Janeiro, entonces capital de la República, durante las décadas de 1940 y 1950. Los millares de pequeños textos publicados por el romancista nordestino en el periódico O Globo, en la columna titulada Conversa de lotação, nunca lanzados en libro por el escritor, revelan lo cotidiano del Distrito Federal sobre la óptica intersubjetiva de sus habitantes. La base para eso son las interpretaciones del cronista con los pasajeros de un medio de transporte colectivo, característico de la ciudad para mediados del siglo XX, en su traslado de la zona sur para el centro de la ciudad. La selección de artículos aquí reproducida busca 
ser una muestra de las cuestiones debatidas en esa especie de espacio público transitorio, el vehículo lotação, por intermedio de sus ciudadanos-pasajeros. Para efectos de recorte de una producción bastante extensa, nos enfocamos en dos ángulos principales: de un lado, el debate nacional en torno de las elecciones para la presidencia de la República, en octubre de 1950; de otro, los problemas de ámbito municipal, relativos al crecimiento urbano de la ciudad en el inicio de ese decenio, a partir de los relatos capturados por la crónica de Lins do Rego, acerca del tráfico y de otros trastornos vividos por la población en el día a día de la ciudad de Río de Janeiro.

Palabras clave: crónica; Río de Janeiro; política; José Lins do Rego; Historia.

Na crônica, como na vida, autor, narrador e personagem estão no turbilhão dos acontecimentos, imersos na indeterminação da história e não têm a vantagem do ponto de vista retrospectivo.

Sidney Chalhoub

(...) nada do que um dia aconteceu pode ser considerado perdido para a história.

Walter Benjamin

\section{Introdução - pesquisa histórica e crítica literária ${ }^{1}$}

Embora concorrentes e, em alguns casos, com princípios antagônicos entre si, a pesquisa histórica e a crítica literária podem mostrar afinidades metodológicas, quando se trata de investigar a obra de um historiador, de um escritor ou de um artista. Além dos aspectos biográficos e da tradicional contextualização, um procedimento recorrente de ambas as áreas consiste na procura pelos vestígios e indícios da produçáo escrita de um autor, de modo a cobrir, ou a renovar, o conjunto de possibilidades analíticas e interpretativas de sua trajetória e produção intelectual.

Entre os pesquisadores das áreas de Letras e de História, em que pesem diferenças e certas rivalidades na investigaçáo de um mesmo tema ou objeto, isso acontece através da

\footnotetext{
${ }^{1}$ O presente artigo contou com a colaboração de Leandro Martan, bolsista de Iniciação Científica do CNPq. Seus autores valeram-se de uma bolsa de Produtividade em Pesquisa (PQ), outorgada pelo CNPq para o triênio 2016-2019, e de uma bolsa de doutorado, outorgada pela CAPES, para biênio 2017-2019.
} 
utilização da crítica genética, do estudo de cartas, da análise de manuscritos, da consulta à biblioteca ou ao acervo do literato, bem como das publicaçóes consideradas menos importantes pela fortuna crítica. Pode-se dizer, sem embargo, que o estudo da crônica constitui um dos gêneros em comum que mais contribui para as convergências, consonâncias e sinergias de pesquisa.

Nesse sentido, as demandas da metodologia científica contemporânea têm trazido desdobramentos no âmbito da pesquisa de pós-graduação no Brasil, com especial atenção para a produção cronística de literatos, apreciada como fontes capazes de lançar novas luzes sobre o conjunto de uma obra ou de um autor. Dissertaçóes e teses têm se dedicado a observar com mais atenção elementos pouco enfatizados com relação a escritores que, segundo o cânone de sua época, alcançaram prestígio e projeção. Exemplos extraídos dos dois campos podem elucidar tal observação.

Entre os historiadores, o interesse pela literatura é crescente no Brasil desde pelo menos os anos 1990. Sob influência da renovação historiográfica europeia e estadunidense, a preconizar o alargamento das fontes da história, os trabalhos de Francisco Foot Hardman (1991), de Nicolau Sevcenko (2003) e de Sidney Chalhoub (2003) abordaram os escritos de Euclides da Cunha, Lima Barreto e Machado de Assis, respectivamente, à luz de parâmetros historiográficos que visam a fisgar a lógica social do texto e que buscam diferenciar-se do cânone da crítica literária acadêmica.

Em adição, pesquisas de cunho coletivo desenvolvidas por historiadores da Unicamp e da PUC-Rio no início do século XXI debruçaram-se em particular sobre a história social da crônica no país, com as coletâneas A história contada (CHALHOUB e PEREIRA, 1998) e História em coisas miúdas (CHALHOUB; NEVES; PEREIRA, 2005), a contemplar uma gama de escritores, que vai de Coelho Neto a Jorge Amado, passando por Mário de Andrade, entre muitos outros.

Com relação aos estudiosos situados no campo da literatura, o pesquisador Álvaro Simóes Jr. (BILAC, 2011) realizou estudo que reuniu as crônicas seriadas de Olavo Bilac autor mais conhecido por sua produção poética -, publicadas entre 1900 a 1908, período da Belle Époque carioca. Foi dessa maneira também que a crônica machadiana, estudada por John Gledson (ASSIS, 2008) desde os anos 1980, contribuiu para redimensionar a maestria das milhares de crônicas, das centenas de contos e das dezenas de romances de Machado de Assis. No mesmo movimento, a pintora Tarsila do Amaral teve a totalidade de seus textos jornalísticos compulsados pela pesquisa de Laura Taddei Brandini (2008), com a abrangência de duas décadas, entre 1936 e 1956.

Caminho análogo vem sendo perseguido nos estudos literários e sociológicos do escritor José Lins do Rego (1901-1957), mais conhecido pelo memorialismo e pelo moderno regionalismo nordestino dos anos 1930. Como se sabe, sua obra principal centra-se na representação ficcional dos ciclos históricos, regionais e sociais do canavial e do sertão do Nordeste 
brasileiro, a exemplo de Fogo morto (1943) e Cangaceiros (1953). Como os demais polígrafos e funcionários públicos de sua época (MICELI, 2001), a colaboração nos jornais legou uma quantidade impressionante de crônicas e artigos publicados ao longo da vida do paraibano, em periódicos da grande imprensa, sendo boa parte delas inéditas em livro.

Nesse caso, o lastro de publicações vai do final dos anos 1910 até fins da década de 1950, quando José Lins do Rego faleceu, no Rio de Janeiro, então capital da República. As crônicas foram publicadas nos jornais das capitais em que residiu - João Pessoa, Recife, Maceió e Rio -, além de um número considerável em impressos de São Paulo, onde não chegou a ser residente, mas aonde ia com certa frequência.

A obra cronística de Lins do Rego foi estudada, em período recente, pelo professor César Braga-Pinto (REGO, 2007), da Northwestern University, que, em seu pós-doutorado, realizado na Universidade de Sáo Paulo, fez um levantamento nos acervos dos arquivos públicos dos estados de Alagoas e da Paraíba para localizar as primeiras colunas do jovem estudante de Direito na imprensa, publicadas entre 1919 e 1924. Já um dos autores do presente capítulo dedicou-se em sua dissertação de mestrado a reunir e analisar as 1.571 crônicas esportivas publicadas por Lins do Rego no Rio de Janeiro, mais precisamente no Jornal dos Sports, de propriedade do jornalista Mário Filho, entre 1945 e 1957 (HOLLANDA, 2004).

Dois outros exemplos acadêmicos, cada um de uma área - Ciências Sociais e Letras -, podem ainda ser arrolados. A socióloga da Unicamp, Mariana Chaguri (2007), em dissertação premiada pela ANPOCS, revisitou os conceitos de regiáo e de regionalismo na abordagem dos romances sociais dos anos 1920 e 1930, enquanto a professora de literatura da Unesp, Juliana Santini (2015), consagrou-se ao mesmo conjunto ficcional do escritor, para destacar o papel do humor na caracterização psicológica dos personagens decadentes de Fogo morto.

\section{Tema e metodologia - cidade, crônica e história}

Em face desse cenário de aproximação temática entre historiadores e pesquisadores da área de Letras, com a subsequente revitalização dos estudos acadêmicos da obra de José Lins do Rego, propormo-nos aqui avançar nessa confluência por meio de um estudo da produção cronística do escritor na cidade do Rio de Janeiro.

De acordo com a trajetória do romancista, Lins do Rego muda-se para a então capital da República em 1935, estimulado pelo reconhecimento público de seus romances memorialísticos, iniciado em 1932, a partir do lançamento de Menino de engenho. A opçáo pela mudança se explica também pela estratégia de atração do editor José Olympio (SORÁ, 2010), que reuniu em torno de si a geraçáo de escritores nordestinos consagrada pelo romance social: a cearense Rachel de Queiroz, o alagoano Graciliano Ramos, o baiano Jorge Amado e o próprio paraibano José Lins. 
Daí em diante, após fixar residência no Distrito Federal, o escritor enraizou-se por mais de duas décadas na cidade e levou com frequência, por meio das crônicas e no exercício do jornalismo local, o ambiente urbano para o centro de suas atençôes de homem de letras radicado no Rio de Janeiro.

José Lins assume, então, o cargo público de fiscal do imposto de consumo em Niterói, cidade que naquela época constituía a capital do Estado do Rio de Janeiro. Para dirigir-se ao trabalho, o romancista pegava as barcas que ligavam as duas cidades, atravessando a Baía de Guanabara. Ademais, durante esse período, na condição de funcionário público, chegou a ser enviado ao interior do Estado a fim de realizar inspeçóes nas cidades de Araruama, Cabo Frio e Vassouras, o que lhe valeu a inspiração para redigir o romance Água-mãe (1941), além de ensaios e crônicas sobre o Vale do Paraíba e a regiáo dos Lagos.

Concorda-se aqui com o argumento do antropólogo Gustavo Sorá, segundo o qual a transferência da geração de escritores para o centro político-cultural da nação é "consequência da ação de cooptação mútua entre o editor e o grupo intelectual nordestino" (2010, p. 183). Por seu turno, Mônica Pimenta Velloso, em seu artigo "Os intelectuais e a política cultural do Estado Novo" (1997), fornece um panorama da atuação do governo varguista em relação às artes e à cultura. Nele, a autora destaca a atuação de modernistas, regionalistas, católicos, socialistas e integralistas que se vincularam de alguma forma ao aparelho de Estado, entre eles: Carlos Drummond de Andrade, Oliveira Vianna, Cecília Meireles, Gilberto Freyre, Vinícius de Moraes, Gustavo Barroso, José Lins do Rego, Manuel Bandeira, entre muitos outros (VELLOSO, 1997, p. 69).

A autora também aponta os mecanismos corporativos de que se valeu o governo estadonovista para funcionar, tal qual um "organismo onipresente que penetra todos os poros da sociedade". Para lograr tal objetivo, erigiu uma ideologia que abarcava "desde as cartilhas infantis aos jornais nacionais, passando pelo teatro, música, cinema e marcando a sua presença inclusive no carnaval” (p. 69).

Embora José Lins viesse a fazer em suas crônicas críticas a Getúlio Vargas, a quem conhecia pessoalmente e com quem mantinha relações críticas porém amistosas, pode-se dizer que o cronista aqui estudado foi um dos integrantes desse sistema político-artístico nacional, já que o vínculo entre Estado Novo e modernismo foi importante na formação da ideia do regime como "defensor de ideias arrojadas no campo da cultura". Mesmo que à revelia, muitos intelectuais foram inseridos, ainda que de forma diferenciada, nos campos de atuação educacional e cultural, com vistas a contribuir para "educar as manifestaçôes populares" (p. 70-71).

Para além da conjuntura política e das posiçóes de poder, é possível apontar, malgrado a distância temporal, uma linha de continuidade de José Lins do Rego e outros modernistas ou regionalistas com a galeria de escritores que tematizou a cidade-capital, desde a virada do século XIX até as primeiras décadas do XX, tais como: Luís Edmundo, Machado de Assis, 
Arthur Azevedo (SICILIANO, 2014), Coelho Netto, Lima Barreto, João do Rio (ANTELO, 2008), entre outros.

Grosso modo, conforme pontua a professora Beatriz Resende (1994), a temática voltou-se para os elementos da paisagem humana, social e urbanística, vivida e representada em meio às transformaçóes promovidas pelos processos de expansão e de modernização urbanas, já presentes em fins do Segundo Reinado, mas intensificados e ressignificados durante a Primeira República (KOK, 2005).

Não obstante, para entender a obra cronística de Lins do Rego, produzida em meados do século XX, deve-se náo apenas evocar essa linhagem que descende do folhetim oitocentista (MEYER, 1996), como sobretudo enquadrar a realidade de que o escritor foi contemporâneo, com a menção às características do jornalismo de então - ainda amplamente influenciado pela imprensa francesa, mas já sob o então recente crescimento da influência da linguagem jornalística estadunidense - e aos seus pares, a exemplo da geraçáo dos cronistas Manuel Bandeira, Rubem Braga (DUBIELA, 2017), Carlos Drummond de Andrade, Clarice Lispector, Nelson Rodrigues e Vinícius de Moraes, entre outros.

Isso para ficar com alguns dos mais expressivos cronistas, referidos por Antonio Candido (2004) em conhecido ensaio sobre a maioridade da moderna crônica brasileira, de composição "aparentemente solta", conquistada a partir dos anos 1930. Trata-se de uma cidade que, ao passar por uma série de planos urbanísticos e ao transformar-se de centro exportador em grande metrópole, triplicava sua população, mudava seu perfil demográfico e alcançava a marca dos dois milhôes de habitantes no ano de 1950 (LESSA, 2005).

O Rio de Janeiro posterior à Revolução de 1930 seria governado por interventores e prefeitos nomeados, a saber: Pedro Ernesto (1930-1936), Henrique Dodsworth (1937-1945), Hildebrando de Góis (1946-1947), Ângelo Mendes de Morais (1947-1951) e João Carlos Vital (1951-1952). Este último seria sucedido por três outros de menor expressão, até chegar a prefeitura de Negrão de Lima (1956-1958), anos antes de ser inaugurada a nova capital, Brasília, e de ser instituído o Estado da Guanabara, em 1960.

A cidade expandia-se de maneira célere, intensa e desordenada, tanto para a Zona Sul, por meio da verticalização de seus prédios, em bairros como Copacabana, objeto de estudo da antropóloga Júlia O’Donnell (2013), quanto para os subúrbios. Estes últimos sofriam os efeitos perversos e excludentes da periferização, prolongando-se pela via férrea, com o adensamento das favelas, inchadas pelas ondas regionais de imigração interna do pós-Segunda Guerra, e com os conjuntos habitacionais originários de políticas de remoção, também em curso nesse período.

O presente artigo procura dar continuidade às pesquisas que vinculam José Lins do Rego à cidade do Rio de Janeiro, com especial atenção à vida cotidiana e às inter-relaçôes entre história e literatura, imprensa e cidade. Para tanto, procedeu-se a uma pesquisa coletiva, desenvolvida pelos autores deste texto junto ao setor de Microfilmes da Biblioteca Nacional, entre 2016 e 2017. 
O foco do levantamento foi o jornal $O$ Globo, para o qual José Lins do Rego colaborou com assiduidade quase diária, durante as décadas de 1940 e 1950, em suas edições "matutina" e "vespertina", a convite de Roberto Marinho. A consulta às milhares de páginas desse periódico permitiu identificar um arco que vai da primeira crônica do escritor, datada de abril de 1944, até a última, que veio a público em dezembro de 1956. Nesse intervalo de mais de 12 anos, computaram-se em torno de 1.700 crônicas.

A danificação dos originais e a impossibilidade de consulta na Biblioteca Nacional a 16 meses de periódico, entre os anos de 1948 e 1949, levam a inferir que mais de dois mil artigos foram assinados por Lins do Rego, apenas para esse jornal. Os textos configuram uma vasta miscelânea, própria à liberdade temática que caracteriza o gênero "polimórfico" da crônica (NEVES, 1994), com o acompanhamento do cotidiano urbano em seus aspectos prosaicos, políticos, sociais, culturais e econômicos.

Encontram-se na coluna de José Lins n'O Globo temas mundanos os mais díspares, que vão da crítica de filmes em cartaz à inauguração de exposiçôes em museus, das viagens ao Nordeste e ao exterior aos comentários políticos sobre o Brasil e o mundo, das críticas a livros recém-lançados a referências múltiplas a personalidades públicas ou anônimas.

Por limitaçóes de espaço, optou-se aqui por um recorte bem preciso, mediante a seleçáo de um segmento de suas crônicas diárias. Propóe-se a leitura seriada de um conjunto de crônicas que, com variaçôes no título - "Conversa de autolotação", "Conversas de lotaçấo", "Concurso de lotação", "Conversa à espera de um lotação" e "Um chofer de lotação" -, abordam o cotidiano de cidadãos em deslocamento na cidade.

O título faz alusão à oralidade e à coloquialidade testemunhada pelo autor no meio de transporte público chamado lotação. Esse meio de locomoção, inexistente nos dias de hoje, consistiu em uma espécie de micro-ônibus, movido a motor de caminhão, com capacidade reduzida de passageiros. Cada veículo comportava até dez pessoas, todas sentadas em bancos enfileirados, a que o cronista chamava de forma sarcástica de "lata de sardinhas", apelido que ele conferiu também a outros meios de transporte superlotados.

Guardadas as devidas proporçóes, pode-se situar o leitor dos dias de hoje com a observação de que os lotaçôes faziam as vezes de vans da época. Constituíam de igual maneira uma solução de emergência do poder municipal para lidar com a precariedade do serviço de transporte público, sendo mais rápidos e de menor custo operacional. Convém lembrar que, naquele período, a cidade ainda convivia, embora de maneira residual, com as linhas de bondes, a ladear espaços nas ruas asfaltadas com automóveis particulares, táxis, ônibus e trens.

Assim como os escritores da belle époque que, em princípios do século XX, faziam da viagem de bonde uma das novidades da eletricidade de entâo, motivo para a matéria-prima de suas crônicas, José Lins do Rego se dedicou a reportar fatos e situaçóes passadas a bordo do lotaçáo, meio de transporte característico do período vivenciado no Rio de Janeiro das décadas de 1930 e 1950 (FREIRE, 2001). 
Em seus anos de residência carioca, entre 1935 a 1957, o cronista habitou em diferentes bairros da Zona Sul da cidade. Primeiro em Botafogo - Rua Conde de Irajá, no ano de 1942 -, depois no Humaitá, mais precisamente no Largo dos Leóes, Rua Alfredo Chaves, entre os anos de 1936 e 1941, onde inclusive hospedou Graciliano Ramos ao sair da prisão do Estado Novo (SANTIAGO, 1981); e, por fim, no Jardim Botânico, Rua General Garzon, no 10 , em terreno adquirido no início dos anos 1940, onde foi construída a casa na qual viveu nos últimos 14 anos de sua vida (HOLLANDA, 2012, p. 151-152).

$\mathrm{Na}$ maior parte do tempo em que viveu na residência do Jardim Botânico - em frente ao Jockey Club da Lagoa e nas proximidades do jardim homônimo -, José Lins do Rego aproveitava suas idas e vindas ao Centro da cidade para publicar crônicas com base em cenas e casos observados durante o traslado. De sua casa, na rua General Garzon, costumava tomar o lotação rumo ao Centro, para almoços na Confeitaria Colombo, em companhia de dirigentes do Clube de Regatas do Flamengo, time de que era torcedor inveterado, e/ou para reuniōes na Livraria José Olympio, situada na tradicional Rua do Ouvidor.

Nessas crônicas, com toques frequentes de ironia, descrevia os tipos humanos, como o chofer do lotação, o grã-fino, a moça sensual, o cavalheiro, o rabugento, o cético, o bem-humorado, o lírico, o nostálgico, o irreverente, o mal-amado, o idoso, o gordo e uma miríade de outros personagens travestidos de passageiros. A bordo do lotaçấo o cronista reencontrava amigos e relatava as circunstâncias dos diálogos que surgiam durante a viagem. Em boa parte das situaçóes o cronista destacava os conflitos e as queixas, os desentendimentos e as discórdias advindos dos debates públicos e políticos que, no transcurso do trajeto, se acaloravam, com a interpolação das opiniôes entre os passageiros.

Não é possível afiançar com exatidão a eventual reelaboração literária ou o grau de ficcionalização por que passavam as curtas narrativas relatadas, mas as histórias levam a crer em seu caráter verídico e em seus personagens reais. Isto porque parte expressiva das crônicas aludia a figuras conhecidas e ao próprio reconhecimento que o escritor, como colunista de um jornal importante da cidade, recebia dos anônimos passageiros.

Do conjunto de publicaçôes encontradas na coluna, entre 24 de abril de 1945 e 25 de maio de 1956, localizaram-se 66 crônicas que giram em torno das conversas de lotação. A seleção a seguir, limitada a exemplos muito pontuais, porém representativos, visa a apresentar ao leitor um apanhado mínimo do teor dos relatos de José Lins do Rego e da atmosfera vivida na cidade. Trata-se de seis crônicas, selecionadas no intervalo que vai de maio de 1950 a dezembro de 1952. Elas compreendem um período histórico de eleiçôes presidenciais, com a candidatura e a vitória de Getúlio Vargas às eleiçôes de 1950, época que coincide com a nomeação à prefeitura do general Ângelo Mendes de Morais e com a posterior eleição do engenheiro João Carlos Vital a este mesmo posto.

Sugere-se o argumento de que o lotação nâo só reflete como reelabora a formação de uma espécie de "esfera pública", no sentido mais consensual definido por Sérgio Costa 
(1995) e pela linhagem habermasiana. Argumenta-se que tal meio de transporte, da maneira enquadrada pelo cronista, adquiria a dimensão de uma arena de opinióes, tribuna dialógica e polifônica, tal como postulada por Bakhtin (BRAIT, 2005).

Ponto de encontro fugaz, o lotação funcionava à maneira de um café, de uma praça ou de uma redação de jornal, a alternar concentração e dispersão. Mais do que um simples veículo motorizado, a cumprir as funçóes de idas e vindas dos moradores da capital da República para seu trabalho e sua moradia, este meio é capaz de apresentar um efeito nivelador e isonômico nas relaçôes entre os habitantes da cidade.

Esses reúnem-se de modo provisório e em circunstâncias fortuitas de deslocamento, no itinerário diário entre a casa e o local de trabalho, favorecendo a discussão em torno de uma "opiniáo pública”. Embora sob o crivo das caracterizações mais ou menos arbitrárias do cronista, a construir ao bel-prazer seus próprios enredos e estereótipos, o nivelamento da condição em que se encontram aqueles cidadãos em trânsito dá ensejo a um tipo de polifonia difusa, de ação comunicativa popular e de sociabilidade urbana particular.

Os problemas relatados nesse microespaço de opinião pública são ora nacionais, ora municipais. Isto é, eles variam da responsabilidade do presidente à competência do prefeito, confluindo para colocar em tela a cidade do Rio de Janeiro dos idos de 1950. O lapso de tempo decorrido entre a espera do lotação e a condução a seu destino final condiciona os diferentes tipos de comentário, os mais variados duelos verbais, o fórum livre de coloquialismos que permitem uma ação e uma performance comunicativa naquele meio de transporte.

Enquanto a simplicidade da escrita da crônica sugere um elementar e efêmero diálogo reportado em jornal, pode-se ao mesmo tempo perceber uma estrutura dialógica, marcada pela afirmação e pela negação sucessiva de opinióes, que se interpolam de acordo com a duração da viagem. $\mathrm{O}$ modo de funcionamento dessa estrutura de comunicação, que revela aspectos importantes da vida social e política do Rio de Janeiro de entâo, pode ser observado através dos exemplos arrolados na seção a seguir.

\section{As conversas de lotação - política, cidade e cotidiano}

A primeira coluna aqui transcrita, datada de maio de 1950, versa sobre uma conversa entretida pelo cronista com um conhecido de lotação, apresentado no texto apenas pelas iniciais em letra maiúscula do nome. $\mathrm{O}$ cronista informa tratar-se de um passageiro frequente e, dentre a gama de assuntos possíveis, ambos escolhem falar de um tema polêmico: as eleiçóes para a presidência da República, prevista para outubro daquele ano.

Uma vez que o interlocutor se mostra entusiasta da candidatura de Getúlio Vargas, José Lins questiona os fundamentos de sua opção. Um e outro contraponteiam pontos de vista, tornam-se logo rivais no debate e procuram realçar a impropriedade dos argumentos alheios. 
Dono da última palavra, ao menos no espaço de reprodução da coluna de jornal que lhe pertencia, José Lins póe termo à crônica com uma frase de efeito a seu favor:

Encontro o meu velho companheiro J.R.C., íntimo das nossas conversas de lotaçấo. E como não nos víssemos há mais de dois meses, muita coisa queria ele saber. Fizemos quase que uma sabatina de conversas. Passamos a enchente, os crimes brutais, a Copa do Mundo, a Taça Rio Branco e, por fim, teríamos que cair na política. J.R.C. É um getulista inflamado e está cheio de entusiasmo pela candidatura do monge de Itu. E como lhe falasse do Brigadeiro ele me argumentou com a farda, e como eu lhe falasse de Cristiano Machado ele me argumentou com a fraqueza de candidatura civil, em momento de agitação militar. Então verifiquei que para o meu amigo só havia mesmo uma candidatura capaz de salvar o país, a de Getúlio Vargas.

- Mas, meu amigo - disse-lhe eu - o nosso querido Vargas, homem de que muito gosto e a quem devo favores bem especiais, já teve tempo bastante para salvar o Brasil e, se não o salvou é porque não teve força para a tarefa.

- Muito boa esta, seu Zé Lins, você quer argumentar com o passado. Eu lhe digo que os tempos do Governo Vargas foram tempos difíceis. E mesmo assim aí estão Volta Redonda, a legislação social, as obras contra as secas. São ou não são obras fundamentais para o Brasil? - É verdade. Outros brasileiros fizeram o mesmo. Aí estão as nossas estradas de ferro, os nossos portos, o saneamento de nossa capital, e não iremos ao cúmulo de arrancar da cova Rodrigues Alves e Campos Salles para Governo Vargas, pelo seu ponto de vista, foi um grande Presidente. Em muita coisa você terá razão. Mas há uma coisa maior que um grande Presidente; há a liberdade de pensar e agir, politicamente, que Vargas liquidou duas vezes. Em 1930 pela revolução, e em 1937 pelo golpe de Estado. Se você me garantisse que, de posse do Governo, Vargas seria um homem da Constituiçáo, tudo estaria bem. Mas o homem que você admira e a quem quero bem e respeito tem fome de Constituição. Já devorou duas. É um autêntico ogro de Cartas Constitucionais.

- O povo quer Vargas. Por toda parte há um desejo sincero pela sua volta.

- É verdade. Não há maior popularidade. Ninguém está mais perto das massas. O general Dutra encontrou um Governo açoitado de vendavais e não soube colher os ventos. Você sabe que não sou governista, mas preciso é que lhe diga que há a eletrificação do São Francisco, como uma obra superior a Volta Redonda. E por acaso haverá nordestino que queira a reeleição do general? Meu amigo, esta história de se justificar o erro por uma quantidade de benefício se parece muito com a cavilaçáo dos escravocratas que justificavam a escravidáo dizendo que os pobres negros libertos iam passar fome. A candidatura de Vargas pode estar, como você me diz, no coração do povo. Mas há razóes que o coração não conhece, que nem mesmo a própria razão conhece. Vargas já foi de uma época. Melhor será conservá-lo no seu tempo.

- Ora, seu Zé Lins, isto é conversa de quem morde e assopra. Se Vargas é o homem em quem você reconhece tantas qualidades, por que temê-lo? 
- Não temo Vargas. Pelo contrário, estimo-o mais do que você imagina. Mas, meu amigo, estimo muito mais este nosso Brasil (REGO, 24 maio 1950, p. 4).

Mesmo depois de findas as eleições, um mês depois da votação, a campanha política nacional continuava a suscitar debate entre os passageiros do lotação. Conforme narra José Lins na crônica abaixo, no caso a diatribe versa sobre a lisura do pleito e o caráter democrático da vitória de Vargas:

Venho em companhia de cinco silenciosos passageiros. Mas logo que chegamos, no começo da rua Voluntários da Pátria, entra o meu amigo J. Norberto e a conversa pegou sobre a maioria absoluta. Norberto é todo ele do golpe. E não faz mistérios de suas intuições.

- Sim, seu Lins, isto de eleição, de voto popular, de verdade das urnas, tem os seus limites. Sou democrata, mas uma coisa é democracia e outra é essa licença [que anda] por aí. Voto, como toda mercadoria, tem o seu valor real. Você não vai querer comparar um Cadillac com qualquer carrinho à toa.

Não gostei da comparação e quis desarticular os argumentos do golpista, mas nem foi preciso. Um cavalheiro que vinha ao meu lado entrou no debate.

- Eu não o conheço e por isto peço desculpas para lhe fazer uma pergunta.

- Pode fazer.

- Mas o Sr. não disse que é um democrata? E se é assim tanto vale o seu voto quanto o meu. O Sr. é voto de Cadillac, eu sou voto de carrinho de mão.

- Não quis chegar a tanto, o senhor não me compreendeu. O que quis dizer é que o voto não deve ser tomado assim com esta indiscriminação geral. Devíamos ter um sistema de filtrar que corrigisse os casos atuais. Vargas ganhou as eleiçóes e, no entanto, a maioria consciente do eleitorado está contra ele. A Nação não está com Vargas.

- E com quem está? Está com Cristiano? Está com o Brigadeiro? Se o senhor somar os votos de Vargas aos votos de Cristiano derrota ainda mais o Brigadeiro; e se somar ao contrário, derrotará ainda mais o Cristiano. Meu amigo, o melhor é ficar quieto e não chorar. Venceu o "baixinho" e a história vai começar.

- Não senhor, ainda não sei quem venceu. Os juízes ainda não falaram. Espere que falem os juízes para cantar a sua vitória. Vargas não foi diplomado, há juristas que não o consideram eleito. Eu, pelo menos, estou convencido que ele não foi eleito.

Aí, vendo que as coisas podiam tomar outro rumo, pois os ânimos se esquentavam, entrei na conversa para que a viagem chegasse a bom termo.

- Norberto, você foi ontem ao jogo?

- Fui, mas que vergonha! O nosso Flamengo está de amargar. Seu Lins, aquilo podia ter sido um banho. 
- E quem ganhou?

- Ora, Lins, não brinca. O Vasco. 4x1. Você não foi ao jogo?

- Fui, mas não posso dizer ainda que o Vasco ganhou.

- Por quê?

- Porque a Federação ainda não aprovou o jogo. Sei lá o que há na súmula do juiz! (REGO, 27 nov. 1950, p. 4)

A crônica seguinte retira de cena o plano nacional e tematiza problemas cotidianos da cidade, como as enchentes que assolavam o dia a dia do carioca. Nesse sentido, o alvo preferencial deixa de ser o presidente da República, Getúlio Vargas, e volta-se ao prefeito do Rio, Ângelo Mendes de Morais. Dessa feita, o cronista se esquiva do confronto e de qualquer protagonismo. Reserva-se ao direito de monologar - ou observar com seus botóes - a discussão entabulada em torno da responsabilidade, ou não, da prefeitura pelos transtornos e alagamentos causados pela chuva torrencial:

Com dez minutos de chuva pesada, a cidade havia se transformado num caudal. Descia água dos morros, alagavam-se as ruas, os carros paravam. Enfim, uma cidade bloqueada pela enchente. No erro de praça, esperávamos que baixasse o nível das águas, como se estivéssemos à beira de um rio sertanejo, aguardando passagem para o outro lado. Aí pegou uma conversa de derrotismo, de desabafo, de Brasil perdido, de povo sem fibra, de gente preguiçosa, como sempre acontece desde que dois brasileiros se encontram para conversar. Sempre que pare um trem, em vista de qualquer acidente, ou que um ônibus fure uma câmara de ar, e que passageiros se entreguem a um bate-papo, o que vai surgir da conversa é a crítica impiedosa ao Brasil, aos políticos, aos administradores. Faz-se uma autocrítica severa, sem dó e sem piedade. Todos nos consideramos indignos da terra que possuímos, das bondades de Deus. Enfim, corta-se de fino no couro do pobre país. Ali, com as águas roncando na rua, com o tráfego paralisado inteiramente, quem apanhou como bicho foi o prefeito Mendes de Morais.

- Culpado é este "general da banda" - dizia um.

- É mesmo - dizia outro. - Prefeito do football, do Carnaval, das Mi-Carêmes. Aí está a cidade sem ralos, com todos os coletores arrebentados, e ele náo faz nada. Só cuida de rainhas disto e daquilo, de estádios para estes negros darem pontapés. E a nossa cidade está aí. Veja o senhor, basta chover meia hora e não há mais cidade, o que existe é um rio roncando ladeira abaixo. Isto é uma vergonha.

Apareceu na conversa um cidadão de certa idade, mas que se opôs à crítica naqueles termos. - Posso falar, porque nem gosto deste Mendes de Morais. Sou oficial do Exército e quando ele esteve no comando das Armas tive até que me haver com ele. É homem de rudezas. Mas não posso esconder a verdade. $\mathrm{O}$ general trabalhou muito pela cidade. Os senhores podem encontrar erros na sua administração. E muitos. Mas que trabalhou, trabalhou. 
- Obras suntuárias - replicou o homem de óculos. - Obras de fachada. Só quis aparecer para poder continuar. Não vou com este tipo.

- Bem, aí o senhor colocou a questão nos termos pessoais. Eu também não vou com ele, mas faço-lhe justiça. Pode ser um grosseirão, mas que trabalha, trabalha de fato. As suas obras estão aí para ser vistas. Não é conversa, não.

A chuva aumentava. As águas cresciam, chegando ao nível da porta do lotação. O chauffeur se irritou:

- Amanhã tenho que levar o carro para a garagem. Melhor é trabalhar na roça.

Roncava um córrego que descia da rua, à esquerda.

- Se durar mais uma hora arrasta os carros parados.

Houve um certo mal-estar no lotação, agora silencioso. Passou ao lado um ônibus, fazendo marolas. O nosso carro dançou na torrente.

- O senhor veja, - continuou o homem de óculos - este prefeito podia tirar uns cobrinhos do football e limpar estes ralos.

Fiquei calado, no meu canto, sem tomar parte nas descargas de pessimismo. Eu também gostava de football (REGO, 20 jan. 1951, p. 4).

A quarta crônica ilustrativa da série também omite o posicionamento do narrador, que, calado, se exime de opinar e assume as vezes de árbitro em meio à controvérsia presenciada em uma viagem. A controvérsia é iniciada por uma "senhora idosa”, sem "papas na língua”, e a discordância generalizada no lotação contrapóe o passado e o presente da cidade, com adeptos saudosistas e ardorosos realistas em lados opostos. $\mathrm{O}$ tema inicial é a lentidão dos transportes públicos, mas logo a crítica resvala para a avaliação geral da qualidade da vida urbana contemporânea:

Sentou-se ao meu lado uma senhora idosa, destas que não tem papas na língua, e foi logo falando mal dos tempos de agora.

- Estou aqui há quase uma hora atrás de um lotação, e só me apareceu este com banquinhos na frente. Este Rio de Janeiro não é mais cidade para se viver, é cidade para se penar. Sou do tempo dos bondes, e digo até que, naquela época, se andava mais depressa. Botafogo, a esta hora, está mais longe do que Cascadura. No tempo do bonde ali na Galeria a gente vinha para o chá na Colombo e chegava em casa e o jornaleiro da Noite nem tinha passado ainda. Saí hoje de casa às 3 horas, andei como diabo e vou chegar em Martins Ferreira quase que às 8 . E dizem que automóvel é ligeiro. O Rio está acabado.

O outro passageiro também falou mal dos táxis.

- Antigamente valia a pena tomar um táxi. Chauffeur era um homem amigo, sabia o nome das ruas e não fazia cara feia ao freguês.

Uma outra senhora tomou a palavra. 
- E os armazéns? A senhora não pode imaginar o que era um armazém em 1925, quando cheguei aqui. O português mandava presente de Natal. E vou contar um fato. Eu tinha uma vizinha casada com um piloto do Lloyd. Pois bem, o marido dela foi para uma viagem à Europa. Faltou dinheiro para pagar o colégio dos meninos e o "seu" Antonio mandou oferecer. E pagou tudo até a volta do marido. Havia amizade naquele tempo.

O meu companheiro do lado aproveitou a oportunidade para criticar o Governo:

- Culpado de tudo é o Governo. Não há Governo neste país.

Aí entrou na conversa outro passageiro:

- Não tem razão o senhor. O mundo destas senhoras é outro mundo. O Brasil não podia ficar nos bondes da Galeria, no armazém do "seu” Antonio. Acontece que nós estamos em 1951.

- Não sou tão velha assim. O Rio que conheci foi de 25 anos atrás. Estava no Governo o Bernardes. Uma dúzia de laranjas custava $\$ 400$. E o Correio um tostão. O homem sensato procurou estabelecer confrontos com cifras. Mas não pegou. $\mathrm{O}$ que existia naquele lotação das sete e meia, com o verão carioca numa tarde maravilhosa, era o Rio, cidade dos bons tempos, contra o Rio, cidade tentacular, cidade dos apertos, das improvisaçóes, da agitação incontida. Não quis falar, mas fui, no meu silêncio compassivo, recordando o ano de 1925, dos grandes dias da "Garnier", do cinema mudo, das viagens mansas de bonde, do estádio do Fluminense, o maior da América do Sul, e tive que dominar as mesmas saudades da velha falante, e concordar com o homem sensato. Aqueles vinte e cinco anos pareciam um século (REGO, 8 dez. 1951, p. 1).

O quinto exemplo foi selecionado pela natureza do incidente extraordinário que suscita a conversa no interior do lotação. Ao contrário dos engarrafamentos anteriores, derivados de chuvas ou do número excessivo de veículos nas pistas, o relato a seguir decorre do trânsito causado pelo enterro de um dos nomes mais populares do rádio e da música de então. Trata-se do velório de Francisco Alves (1898-1952), intérprete de famosas cançóes e cognominado o "rei da voz". Os argumentos contra a comoção de uma multidão que paralisa o dia útil de trabalho da cidade, com o falecimento de seu ídolo musical, mobilizam as tradicionais caracterizaçóes do brasileiro como "povo" preguiçoso, interessado em assuntos desprezíveis, de menor importância, tais quais a música popular e o futebol.

A despeito da existência de um passageiro especialmente irritado e incomodado, a comoção das ruas acaba por contagiar a maioria dos que se encontravam no lotação, incluindo o condutor:

Estávamos engarrafados. O tráfego todo parado, sem que houvesse esperanças de próxima solução. Como quase todo carioca que se presa, tratei de entregar-me ao irremediável e esperar que Deus desse bom tempo. Mas um de meus companheiros não estava para tanto, e desabafou em termos de irritação: 
- Veja a que está reduzido este país. Tudo isto por causa de um cantor de rádio que morreu. O Brasil, em dias de hoje, só se comove pelo que é insignificante, pelo que não traz dignidade alguma. País de cantor de rádio e jogador de football.

Os outros companheiros não tomaram conhecimento da veemência do homem insatisfeito e violento. $\mathrm{O}$ calor dentro do carro nos afligia. Nisto parou ao nosso lado, próximo à calçada da praia, uma senhora bem vestida, toda de preto. Era uma bela mulher. E deixou-nos constrangidos, porque começou a chorar. Aos poucos o grupo cresceu. Carros e multidão mergulhados no mesmo poço, no asfalto incandescente do Flamengo. Outra senhora aos prantos, esta uma quase anelá, gritou em desespero:

- Coitadinho dele! Está morto! Não canta mais!

As exclamações da velha contagiaram o grupo. Agora quase todas as mulheres que estavam na expectativa da passagem do féretro abriram a boca num berreiro de velório à saída do defunto. Positivamente, não posso deixar de confessar: o meu pobre coração de sentimentalão estremeceu nas suas bases nordestinas. Senti um frio lá por dentro. Salvou-me a agressividade do companheiro irritado:

- Isto é uma vergonha! Um povo de inconscientes. Veja esta velha. Estou certo de que deixou em casa um marido paralítico sem ter o que comer para o almoço, e vem dar este espetáculo de histerismo retardado.

A multidão crescia por todos os lados. Havia gente trepada em cima das árvores, em cima dos automóveis. Janelas de edifícios cheias de curiosos, de fấs inconsoláveis. Vi lágrimas nos olhos de um soldado de tráfego. E cada vez mais cresciam o choro, o pranto, as lamentaçóes em voz alta. Uma cidade inteira aos soluços no meio da rua. O chauffeur do nosso carro já havia abandonado a direção e estava no outro lado, à procura de conseguir ver de mais perto o caixão do cantor, que vinha carregado pela massa. Aí houve um paroxismo contagioso. Uma mocinha deu para gritar e caiu na calçada, nos estertores de um ataque de nervos. Subiu-me à garganta aquele angustioso nó do choro contido. Mas tive medo do homem terrível.

Depois que a crise foi-se diluindo e a multidão já ia quase no fim, olhei para os companheiros do lotação e vi que lágrimas tinham andado pelos olhos vermelhos de alguns. E, como o homem viesse com mais palavras duras, eu náo contive e lhe disse:

- O senhor tem razão. Ainda resta, a este povo que nada tem, esta liberdade de abrir o coração à vontade. Este cantor deu-lhe alguma coisa de maior que o pão, deu-lhe as delícias de suas cantigas. Com o seu violão curou muitas feridas, ajudou muita gente a viver, a amar. Este povo é maior do que o senhor pensa. Pelo menos tem a gratidão das lágrimas abundantes.

$\mathrm{O}$ carro ficou em silêncio. Mas aconteceu uma coisa que nos deixou contrafeitos. O chauffeur voltou-se para trás e nos disse com voz rouca de raiva:

- Não levo mais este senhor que está aí. No meu carro não anda um inimigo do Chico.

E não houve mais nada. Apenas o passageiro saltou do lotação e, virando-se para nós, como se fôssemos toda a cidade de loucos, nos filou com o olhar de mais desprezo que já vi em olhos humanos (REGO, 4 out. 1952, p. 3). 
A sexta e última crônica desta seleçâo foi escolhida por ilustrar um curioso debate acerca das prioridades que a prefeitura deve levar em conta ao cuidar da cidade. Dessa vez, a opinião emitida por José Lins do Rego está no centro das discussôes e, sendo pivô do quiproquó, torna-se alvo predileto de ataques coletivos. O pomo da discórdia gira em torno da necessidade de embelezamento dos jardins públicos, aspecto defendido pelo cronista, em detrimento dos problemas mais urgentes que afligem os cariocas em seu dia a dia, posição esta da maioria dos passageiros. A cada argumento a favor e contra a preocupação, por assim dizer estetizante do autor, passa a ser ridicularizada pelos presentes no lotação:

Encontro-me em pleno "bate-papo" com um cidadão que nunca vira. Logo de saída, manifestara-se aborrecido com o jardim da praia de Botafogo. Achava que o Prefeito gastara muito dinheiro ali, quando podia ter empregado aquela verba em serviços mais práticos. $\mathrm{O}$ jardim, de fato, era uma beleza, mas o carioca precisava de mais coisas para viver do que de beleza. Não tínhamos água para tomar banho, não tínhamos ruas calçadas pelos subúrbios. Os jardins que esperassem para os dias de fartura. Fui obrigado a discordar do homem falante. Tínhamos tanta precisão de jardim como de água. Uma cidade, como uma pessoa viva, não podia adiar as suas necessidades de trato do corpo. Aquele jardim valia tanto para a cidade como uma nova adutora, porque lhe dava aquilo com que sonham as mulheres para nos deslumbrar: dava-lhe a sedutora aparência, o encanto do corpo.

$\mathrm{O}$ homem falante não se convenceu com os meus argumentos hedonistas e me replicou: - Vê-se que o senhor é de festa. Um jardim é obra adiável, é uma alegria para quem não precisa de outras coisas essenciais. A nossa cidade não pode nem recolher o lixo das ruas, somos a cidade mais suja do mundo, e vem o senhor a me falar na beleza dos jardins. Jardim é luxo e as cidades que nấo podem com este luxo deviam cuidar de se mostrar, em primeiro lugar, com decência. De que nos serve este jardim se em minha casa, hoje pela manhã, faltou-me água nas torneiras?

Em favor do falante veio outro companheiro:

- Não tenho água em casa há uma semana.

$\mathrm{O}$ homem se animou para me esmagar definitivamente.

-É, mas temos jardins.

Já tínhamos atravessado a avenida Oswaldo Cruz e o carro foi obrigado a parar pelo acúmulo do tráfego, àquela hora da manhã em estado de agonia. $\mathrm{O}$ calor tremendo tirava faíscas do asfalto. $\mathrm{O}$ silêncio que se estabeleceu foi quebrado pelo falante, que ainda queria tripudiar sobre mim.

- Mas temos jardins, não é verdade?

Aí não me contive mais.

- É verdade, amigo, ainda não temos bastantes jardins. Fique certo o senhor de que uma cidade tâo protegida como o Rio pela natureza deve o mais que puder plantar jardins, cobrir-se 
de flores, de plantas belas, do que há de mais característico em sua flora. Se D. João VI pensasse como o senhor não teríamos o Jardim Botânico. O rei D. João devia sentir mais necessidades do que nós nesta cidade, que era um burgo podre, e no entanto teve alegria de sobra para plantar as palmeiras régias e criar um horto que é a nossa maior riqueza botânica. Uma cidade não é só as utilidades que nos dão conforto. É mais do que isto, que é o seu grau de progresso. Uma cidade não deve ser somente uma doméstica a serviço das nossas necessidades: precisa ser um motivo de beleza para contentar as nossas disponibilidades líricas.

Compreendi que estava caindo no ridículo, porque todo o carro sorriu. Mas quando chegamos à Praça Paris os canteiros enchiam-nos a vista de cores maravilhosas. Senti-me recompensado. $\mathrm{O}$ ridículo já não me doía na vaidade. Até me senti satisfeito de ter sofrido um pouquinho pelos jardins cariocas (REGO, 6 dez. 1952).

\section{Contextualização da pesquisa e comentários às crônicas}

Transcrevemos acima trechos de seis de um total de pouco mais de 60 crônicas da série reunidas no decorrer do levantamento das publicaçôes jornalísticas. Em seu conjunto apresentam assuntos variados que versam sobre cinema, política, urbanismo, clima, entre muitos outros. O primeiro texto da série veio a lume na edição de 23 de abril de 1945, sob o título Conversa de autolotação e o último, com letras em caixa alta no jornal, intitulado Conversa de lotação, teve publicação em 24 de maio de 1956.

Desde a primeira publicação, constata-se uma amplitude no temário escolhido pelo autor, como a menção ao contexto político internacional, que aparece na crônica de abril de 1945. Nela, José Lins comenta a queda de Berlim na Segunda Guerra Mundial, noticiada então pelo rádio, enquanto ainda no mesmo texto trata do Vasco da Gama, comentando mais uma partida daquele time carioca pelo campeonato local. Assim, o lotação avulta não apenas como meio de transporte, mas como repositório de notícias multifacetadas, em que o cotidiano, a vida política e os interesses gerais dos cidadãos se entrecruzam.

A compreensão mais ampla das crônicas de José Lins e da pluralidade de seus temas requer considerações sobre o contexto político da cidade, como já dito, então capital federal. No artigo "As reformas urbanas na cidade do Rio de Janeiro: uma história de contrastes" (RODRIGUES e OAKIM, 2015), os pesquisadores Antônio Edmilson Martins Rodrigues e Juliana Oakim apresentam um histórico das reformas urbanas projetadas na cidade e seu impacto no dia a dia citadino.

O tópico do artigo dedicado à cidade na Era Vargas (1930-1945/1951-1954) assinala que esse período foi importante na incorporação "dos segmentos populares excluídos anteriormente, num sinal claro de moralidade e de definição da capital como símbolo de uma nova era de trabalho e indústria” (2015, p. 35). Quanto às posiçóes políticas na Era Vargas, os autores postulam que na década de 1950: 
a cidade viu surgir, em alguns de seus bairros mais tradicionais, um movimento de reação às medidas progressistas e vanguardistas dos anos 1950. A sociedade carioca se dividia entre aqueles que defendiam Getúlio e os que o combatiam. A polêmica ganhou os meios de comunicação com o debate de posiçóes que se apresentavam sob a forma do grande debate nacional nas páginas dos jornais Última Hora e Tribuna da Imprensa, que colocava diante do primeiro a figura de Vargas e diante do segundo o grande líder da direita conservadora, o político da UDN, Carlos Lacerda (p. 37-38).

O lotação é o meio de transporte que surge na década de 1940 como alternativa à demanda de transporte público, em virtude do racionamento de gasolina e óleo na cidade do Rio. Embora a população carioca assistisse aos constantes acidentes e às imprudências de seus condutores, o veículo, segundo um dicionário de curiosidades dos anos 1960, "foi apontado por mais de 20 anos como o mais rápido e útil transporte da cidade. Hoje, inteiramente desaparecido da Zona Sul, está servindo somente na Zona Norte" (CAMPOS e SILVA, 1965, p. 167).

Em abono à observação acima, o escritor húngaro Peter Kellemen (1961), em sua descrição do lotação para um livro inusitado sobre a cidade também no decênio de 1960, inclui diversas informaçóes sobre esse transporte: a) o lotação era muito concorrido entre os passageiros, de modo que o autor estrangeiro sugere em seu manual bem-humorado como conseguir vaga em um deles; b) as mulheres não costumavam dar preferência ao lotação por ser um transporte de muito contato físico entre os passageiros; c) os lotaçôes ficavam vazios fora dos horários de pico da cidade; d) os motoristas dos lotaçóes costumam dirigir com velocidade desmesurada, talvez porque o cargo era comissionado, fazendo-os acelerar para faturar o maior número de viagens por dia.

Diante disso, como entender a escolha de José Lins do Rego para privilegiar os personagens, os assuntos e as situações nesse meio de transporte específico em suas crônicas? Face à longevidade da sua colaboração cronística e à rede de sociabilidade a que pertencia o romancista-jornalista, pode-se enquadrá-lo tanto na tradição dos cronistas cariocas finisseculares - século XIX para o XX -, como João do Rio, em contato com as ruas da cidade, quanto no projeto do modernismo brasileiro, cujo estreitamento com a polifonia da esfera pública urbana almejava superar o beletrismo e a redoma do escritor cultivador da "arte pela arte".

A presença dos literatos no espaço polifônico das grandes cidades é alvo de uma matéria na revista Diretrizes, publicada em julho de 1938, que traz o seguinte comentário em texto intitulado "Os escritores vivem nas ruas":

Cabe aos entendidos tirar conclusóes e verificar até que ponto essa circunstância influi na produção literária nacional assim como pesquisar os motivos dessa penúria. Nós apenas registramos: 
- O poeta Jorge de Lima tem uma sapataria, o escritor Graciliano Ramos esteve trabalhando como caixa de uma casa comercial, o escritor José Lins do Rego é fiscal do imposto de consumo, o novelista Marques Rebelo é vendedor da Cia. Nestlé, o economista Leonidas de Rezende cria galinhas e planta laranja, o poeta Schmidt é diretor de produção de uma cia. de seguros, Anibal Machado, Murilo Mendes, Adelmar Tavares e outros são funcionários da Justiça. E assim por diante (DIRETRIZES, jul. 1938, p. 64).

Notório torcedor de futebol, literato expansivo e exuberante, conforme testemunha Otto Maria Carpeaux no prefácio ao romance Fogo morto (REGO, 1943), os principais pontos de sociabilidade e atuação de José Lins foram o Clube de Regatas do Flamengo, sediado na Gávea - bairro vizinho à sua casa, que ele acessava caminhando às margens da Lagoa Rodrigo de Freitas -, a Confeitaria Colombo e a Livraria-Editora José Olympio, situada no Centro da cidade, na Rua do Ouvidor. A rotina do escritor, segundo testemunham familiares, incluía a frequência a clubes sociais como o Piraquê, na Lagoa Rodrigo de Freitas, próximo à sua última residência, onde jogava tênis com os amigos e a família.

A produção cronística de José Lins do Rego não pode ser descontextualizada também do suporte jornalístico de origem e da esfera de posicionamentos políticos do jornalismo na capital da República. Conforme fundamenta o historiador Nelson Werneck Sodré (1999), em sua história da imprensa no Brasil, o jornal O Globo, de que Lins do Rego torna-se colaborador regular nos anos 1940 e 1950, fazia oposição à política varguista na conjuntura do segundo governo, entre 1951 e 1954.

Mas, para que se entenda melhor como a evolução desse posicionamento se dá, observe-se que o periódico fora fundado em 1925 pelo jornalista e empresário Irineu Marinho (1876-1925) e que a época da fundação d'O Globo corresponde ao fim do governo Artur Bernardes (1922-1926), ocasião na qual o jornal se declara livre de afinidades políticas, econômicas ou ideológicas.

Tal discurso dizia interessar-se tão somente pelas questões do funcionalismo público, pelo combate à carestia e pela crítica à falta de infraestrutura e conservação da cidade. Não obstante a retórica, a ressaltar uma suposta isenção em prol de um interesse pelos problemas municipais da população, O Globo posiciona-se no final dos anos 1920 contra a candidatura de presidente Washington Luís (1926-1930), bem como evidencia simpatia à Coluna Prestes e aos tenentes revoltosos ao longo daquele decênio.

Em seguida, o jornal apoia a Revolução de 1930 e, em sua esteira, saúda a formação da junta militar, liderada pelos generais Tasso Fragoso, João de Deus Mena Barreto e pelo almirante Isaías de Noronha. Durante a Era Vargas, o jornal não deixou de criticar as decisóes do governo varguista, mas manteve-se a favor do desenvolvimento da legislação trabalhista.

Já no fim do Estado Novo, o periódico coloca-se favorável à deposição do presidente e da redemocratização do país, e cerra fileiras contra os comunistas, liderados pelo PCB de Luís 
Carlos Prestes. Na agenda econômica, o jornal defendia os princípios liberais e, em termos políticos, mostrava-se contra a volta de Vargas ao poder nos anos 1950, mantendo-se relativamente imparcial no que se refere aos outros candidatos à presidência.

José Lins do Rego foi amigo próximo do empresário Roberto Marinho e percebe-se em sua coluna a adesão às linhas gerais do posicionamento político do periódico. Marinho, em 1943, convida-o para publicar no jornal e nele passa a colaborar quase que diariamente até a sua morte, em 1957. A série de crônicas que leva o nome "Conversa de lotação", tem início nove anos depois da chegada do paraibano e de sua família à cidade do Rio de Janeiro, e continuaria por doze anos.

Pode-se conjecturar que a matéria-prima das inspiraçóes para as conversas de lotação foram os trajetos casa-trabalho e casa-livraria: além de praticar tênis, José Lins gostava de ir ao cinema com toda a família. Quando ia ao Centro, pegava um lotação no ponto do Jockey Club e com base no que ouvia dos passageiros extraía temas para as suas crônicas do dia seguinte no jornal O Globo (HOLLANDA, 2012, p. 62).

Nesses textos de José Lins, é possível identificar o retrato dos tipos urbanos cariocas - o chofer, o dentista, o político, o literato, o bancário -, em situaçóes vividas e/ou imaginadas pelo cronista, relacionadas ao meio ambiente, às paisagens, à linguagem do cotidiano e às tradiçôes, aos hábitos e costumes da população da cidade - alimentação, futebol, lazer, vestuário. Os habitantes relatavam ao escritor queixas e inquietaçôes cotidianas, algumas delas transversais a diferentes classes sociais, motivadas por notícias divulgadas pelo próprio jornal carioca em que o escritor publicava.

As crônicas não tratavam apenas da cidade ou da política nacional, e estendiam-se às viagens realizadas pelo paraibano, dialogando com ideias esposadas por Gilberto Freyre. Em artigo de 1950, intitulado "A propósito do memorialismo de José Lins do Rego" (FREYRE, 7 nov. 1950), o sociólogo pernambucano trata da díade memória-invenção, outra forma de se referir ao par realidade-ficção nos romances zelinianos.

É possível aqui relacioná-la também à interpretação da produção cronística de José Lins do Rego que, aqui e ali, também menciona Recife, Maceió, Caruaru, Campina Grande, Mamanguape, entre outras cidades nordestinas. Segundo Mariana Chaguri:

Freyre argumenta que a imaginação não cria inventando, antes, a imaginação combina aquilo que existe por meio da memória, de modo que, a segunda seria a base da primeira. Assim, nada seria criado de modo absoluto, isto é, o criador seja artístico, científico ou literário apenas descobre relaçōes novas "entre pessoas e coisas. Entre pessoas e animais. Entre pessoas e fatos. Entre épocas. Entre sociedades humanas. Entre os sentidos, os órgãos, os chamados instintos do homem e a sua inteligência" (CHAGURI, 2007, p. 93).

Ainda nesse sentido, o prefácio ao livro de memórias Meus verdes anos considera a importância do papel mnemônico da evocação e da recordação: 
Fiz livro de memórias, com a matéria retida pela engrenagem que a natureza me deu. Pode ser que me escape a legitimidade de um nome ou de uma data. Mas me ficou a realidade do acontecido como o grão na terra. A sorte está em que a semente não apodreça na cova e que o fato não tenha o pobre brilho do fogo-fátuo. É tudo o que espero dos "verdes anos" que se foram no tempo, mas que ainda se fixam no escritor que tanto se alimenta de suas substâncias (REGO, 2011, p. 18).

Desse modo, é possível identificar as relações entre pessoas e lugares na tematização das crônicas de José Lins. $\mathrm{O}$ autor procurava selecionar temas comezinhos que, ao mesmo tempo, seduziam o leitor pela sua concretude e veracidade no espaço diário de um jornal. Isto dava margem para refletir não só as questóes cotidianas da cidade, mas do Brasil e do mundo. Embora os textos acima selecionados circunscrevam-se à eleição de Vargas no final dos anos 1940, uma série de outros políticos será tematizada na coluna ao longo da década de 1950, tais como Carlos Lacerda, Juscelino Kubitschek e Jânio Quadros.

\section{À guisa de conclusão}

O propósito mais amplo deste artigo foi apresentar ao leitor uma faceta menos conhecida da produção não romanesca de José Lins do Rego, contribuindo para rever sua fortuna crítica e a cristalização - ou confinamento - de sua imagem na história literária nacional. À luz dessa proposta, a tematização que o romancista faz do Rio de Janeiro mostra-se apropriada, porquanto permite inscrever o escritor nordestino em um rol de cronistas modernos que trataram de questóes da capital da República em seu dia a dia (VONK, 2013). Em meio a uma imprensa também em transição nos anos 1950 (ABREU, 1996), foi possível acompanhar, nos limites espaciais conferidos pelo gênero da crônica veiculada em jornais, as referências cotidianas à cidade.

Cientes da impossibilidade de esgotar a análise, limitamo-nos acima a uma apresentação panorâmica e à reprodução de exemplos representativos, capazes de dar uma dimensão concreta do estilo e do conteúdo desses escritos inéditos. Procurou-se com isso também compartilhar as aproximaçôes e os distanciamentos que o "sabor do tempo" proporciona aos leitores, aos pesquisadores da história-memória do Rio de Janeiro e, eventualmente, até mesmo aos moradores cariocas.

Destarte, as conversas de lotação permitem flagrar instantes pitorescos, expressões coloquiais e reclamaçóes contumazes, entre outros aspectos interessantes da vivência do Rio de Janeiro da década de 1950. A caracterização dos tipos sociais, a leveza do humor, a descrição de pontos topográficos e a enunciação de problemas ordinários vivenciados pela população são os elementos mais evidentes postos em narração pelo cronista. 
O cenário descortinado remonta a meados do século passado, conjuntura histórica em que se assiste a um crescimento demográfico significativo na cidade e ao desencantamento com as promessas de transformação urbana decorrentes dos projetos de modernidade de início do século XX, mas que o nacional-desenvolvimentismo iria encampar e reinventar logo depois, durante a Era JK, redirecionando-os para Brasília, novo locus e vetor da capitalidade.

Nesses diminutos relatos, em breves e por vezes mal traçadas linhas, escritas por assim dizer em moto-contínuo ou estagnadas no trânsito da metrópole caótica, em meio à banalidade do ir-e-vir da semana de trabalho, o Centro do Rio - Avenida Rio Branco, Presidente Vargas, Central do Brasil, Cinelândia, Praça Paris e Avenida Beira-Mar - e os bairros da Zona Sul - Leme, "balneário de Copacabana", Botafogo, Humaitá e Jardim Botânico - ganham especial relevo na paisagem jornalística.

Em menor grau, as crônicas não deixam de se referir a bairros da Zona Norte e do subúrbio, como Méier, Maracaná, Cascadura e Bangu. De todo modo, dá-se destaque às cenas relativas ao fluxo dos seus cidadãos nos meios de transporte e às dificuldades de deslocamento interpostas entre as duas regiōes, uma de moradia outra de labuta, na cidade.

Mais do que uma crítica de costumes, a ambiguidade das conversas e do gênero camaleônico da crônica - atrelada à realidade, mas condicionada à recriação literária do cronista-repórter - revelam o jogo de escalas na temática eleita por seus atores, propiciando um inusitado e efêmero microcosmo da "opiniáo pública".

$\mathrm{O}$ alvo preferencial são os personagens citadinos e nele incluem-se os próprios escritores - não raro, José Lins do Rego é persona pública reconhecida e interpelada pelos passageiros durante a viagem -, mas também o cantor de rádio e o jogador de futebol, o prefeito da cidade e o presidente da República. A “vida ao rés do lotação" permite trafegar do micro ao macro, e deste àquele, com a alternância niveladora dos discursos de personagens anônimos, de figuras públicas e de personalidades artísticas - a exemplo do caricaturista Álvarus ou do escritor João Condé -, que ganham vulto em meio aos relatos das situaçôes e das agruras corriqueiras por estes enfrentadas.

Os percalços da polis periférica e excludente continuam a olhos vistos nos dias de hoje, na combustão motorizada, ruidosa e poluente, nos buracos das ruas mal pavimentadas da cidade. Tais percalços fazem ecoar o debate mais amplo sobre a insatisfação do carioca ante o alheamento de figuras da política nacional e ante a qualidade precária dos serviços prestados pelo poder municipal.

\section{Fontes primárias}

REGO, José Lins do. "Conversa de lotação". O Globo, 24 maio 1950.

REGO, José Lins do. "Conversa de lotação". O Globo, 27 nov. 1950. 
REGO, José Lins do. "Conversa de lotação". O Globo, 20 jan. 1951.

REGO, José Lins do. "Conversa de lotaçáo”. O Globo, 08 dez. 1951.

REGO, José Lins do. "Conversa de lotação". O Globo, 04 out. 1952.

REGO, José Lins do. “Conversa de lotação”. O Globo, 06 dez. 1952.

Revista Diretrizes, ano I, n. 4, jul. 1938, p. 64. Seção Sociologia-Literatura-Arte.

\section{Série consultada - jornal $O$ Globo}

REGO, José Lins do. "Conversa de autolotação", 23 abr. 1945.

REGO, José Lins do. "Conversa de autolotação", 3 jul. 1946.

REGO, José Lins do. "Conversas de autolotaçáa”, 16 jul. 1946.

REGO, José Lins do. "Conversas de lotação", 25 set. 1946.

REGO, José Lins do. "Concurso de lotação", 14 out. 1946.

REGO, José Lins do. "Conversa de lotação", 22 out. 1946.

REGO, José Lins do. "Conversas de lotação", 27 nov. 1946.

REGO, José Lins do. "Conversa de lotação", 28 dez. 1946.

REGO, José Lins do. "Conversa de lotação", 26 fev. 1947.

REGO, José Lins do. "Conversa de lotação", 10 maio 1947.

REGO, José Lins do. "Conversa de lotaçâo", 02 jun. 1947.

REGO, José Lins do. "Conversa de lotação", 05 jul. 1947.

REGO, José Lins do. "Conversa de lotação", 13 ago. 1947.

REGO, José Lins do. "Conversa de lotação”, 21 mar. 1949.

REGO, José Lins do. "Conversa de lotação", 31 mar. 1949.

REGO, José Lins do. "Conversa de lotação", 4 abr. 1949.

REGO, José Lins do. "Conversa de lotação - Rural”, 20 maio 1949.

REGO, José Lins do. "Conversa de lotação", 7 jun. 1949.

REGO, José Lins do. "Conversa de lotação", 28 jun. 1949.

REGO, José Lins do. "Conversa de lotação", 7 jan. 1950.

REGO, José Lins do. "Conversa de lotação”, 2 fev. 1950.

REGO, José Lins do. "Conversa de lotação", 18 fev. 1950.

REGO, José Lins do. "Conversa de lotação", 6 mar. 1950. 
REGO, José Lins do. "Conversa de lotação", 24 maio 1950.

REGO, José Lins do. "Conversa de lotação", 26 out. 1950.

REGO, José Lins do. "Conversa de lotação", 15 jan. 1951.

REGO, José Lins do. "Conversa de lotação", 20 jan. 1951.

REGO, José Lins do. "Conversa de lotação", 5 dez. 1951.

REGO, José Lins do. "Conversa de lotação", 6 dez. 1951.

REGO, José Lins do. "Conversa de lotação", 8 dez. 1951.

REGO, José Lins do. "Conversa de lotação", 11 dez. 1951.

REGO, José Lins do. "Conversa de lotaçáo", 10 jan. 1952.

REGO, José Lins do. "Conversa de lotação", 11 jan. 1952.

REGO, José Lins do. "Conversa de lotação”, 14 jan. 1952.

REGO, José Lins do. "Conversa de lotação", 17 jul. 1952.

REGO, José Lins do. "Conversa de lotação", 27 set. 1952.

REGO, José Lins do. "Conversa de lotaçâa”, 4 out. 1952.

REGO, José Lins do. "Conversa de lotação", 7 out. 1952.

REGO, José Lins do. "Conversa de lotação", 11 out. 1952.

REGO, José Lins do. "Conversa de lotação", 20 out. 1952.

REGO, José Lins do. "Conversa de lotação", 25 out. 1952.

REGO, José Lins do. "Conversa de lotaçáo”, 1º nov. 1952.

REGO, José Lins do. "Conversa de lotação", 6 dez. 1952.

REGO, José Lins do. "Conversa de lotaçáo”, 17 jan. 1953.

REGO, José Lins do. "Conversa de lotação", 31 jan. 1953.

REGO, José Lins do. "Conversa de lotação", 14 abr. 1953.

REGO, José Lins do. "Conversa de Lotação", 15 ago. 1953.

REGO, José Lins do. "Conversa à espera de um lotaçáo", 5 out. 1953.

REGO, José Lins do. "Conversa de lotação", 3 dez. 1953.

REGO, José Lins do. "Conversa de lotaçâo”, 11 out. 1954.

REGO, José Lins do. "Conversa de lotação", 3 nov. 1954.

REGO, José Lins do. "Conversa de lotação", 3 fev. 1955.

REGO, José Lins do. "Conversa de lotação", 25 maio 1955.

REGO, José Lins do. "Conversa de lotação", 22 out. 1955.

REGO, José Lins do. "Conversa de lotação", 14 jan. 1956.

REGO, José Lins do. "Conversa de lotação", 20 fev. 1956. 
REGO, José Lins do. "Um chofer de lotação", 16 mar. 1956.

REGO, José Lins do. "Conversa de lotação", 11 abr. 1956.

REGO, José Lins do. "Conversa de lotação", 13 abr. 1956.

REGO, José Lins do. "Conversa de lotação", 24 maio 1956.

\section{Referências}

ABREU, Alzira Alves (org.). Imprensa em transição: o jornalismo brasileiro nos anos 1950. Rio de Janeiro: FGV Editora, 1996.

ANTELO, Raul (org.). João do Rio - A alma encantadora das ruas. São Paulo: Companhia das Letras, 2008.

ASSIS, Machado de. Bons dias! Organização de John Gledson. Campinas: Editora Unicamp, 2008.

BILAC, Olavo. Registro: crônicas da Belle Époque carioca. Organização de Álvaro Santos Simôes Jr. Campinas: Editora Unicamp, 2011.

BRAIT, Beth (org.). Bakhtin: dialogismo e construção do sentido. Campinas: Editora Unicamp, 2005.

BRANDINI, Laura Taddei (org.). Crônicas e outros escritos de Tarsila do Amaral. Campinas: Editora Unicamp, 2008.

CAMPOS, Alexandra; SILVA, Da Costa e. Dicionário de curiosidades do Rio de Janeiro. São Paulo: Comércio e Importação de Livros, 1965.

CANDIDO, Antonio. A vida ao rés-do-chão. In: CANDIDO, Antonio. Recortes. Rio de Janeiro: Ouro sobre Azul, 2004.

CHAGURI, Mariana. O romancista e o engenho: José Lins do Rego e o regionalismo nordestino dos anos 1920 e 1930. São Paulo: Anpocs; Hucitec, 2007.

CHALHOUB, Sidney. Machado de Assis historiador. São Paulo: Companhia das Letras, 2003.

CHALHOUB, Sidney; PEREIRA, Leonardo (orgs.). A história contada: capítulos de história social da literatura brasileira. Rio de Janeiro: Nova Fronteira, 1998.

CHALHOUB, Sidney; NEVES, Margarida de Souza; PEREIRA, Leonardo (orgs.). História em coisas miúdas: capítulos de história social da crônica no Brasil. Campinas: Editora Unicamp, 2005.

COSTA, Sérgio. A democracia e a dinâmica da esfera pública. Lua Nova - revista de cultura e política, CEDEC, São Paulo, n. 36, 1995, p. 55-65. Disponível em: http://www.scielo.br/ 
scielo.php?script=sci_arttext\&pid=S0102-64451995000200004\&lng=en\&nrm=iso\&tlng =pt. Acesso em: 19 nov. 2018.

DUBIELA, Ana Karla. As cidades de Rubem Braga e Walter Benjamin: flanando entre Rio, Cachoeiro e Paris. Fortaleza: Lumiar, 2017.

FREIRE, Américo. Guerra de posiçôes na metrópole: a prefeitura e as empresas de ônibus no Rio de Janeiro (1906-1948). Rio de Janeiro: FGV Editora, 2001.

FREYRE, Gilberto. A propósito do memorialismo de José Lins do Rego. Diário de Pernambuco, Recife, 7 nov. 1950.

HARDMAN, Francisco Foot. Trem fantasma: a modernidade na selva. São Paulo: Companhia das Letras, 1991.

HOLLANDA, Bernardo Borges Buarque de. O descobrimento do futebol: modernismo, regionalismo e paixão esportiva em José Lins do Rego. Rio de Janeiro: Ediçóes Biblioteca Nacional, 2004.

HOLLANDA, Bernardo Borges Buarque de. ABC de José Lins do Rego. Rio de Janeiro: Editora José Olympio, 2012.

KELLEMEN, Peter. Brasil para principiantes. Rio de Janeiro: Civilização Brasileira, 1961.

KOK, Glória. O Rio de Janeiro na época da Avenida Central. Rio de Janeiro: Bei Comunicação, 2005.

LESSA, Carlos. O Rio de todos os Brasis. Rio de Janeiro: Record, 2005.

MEYER, Marlyse. Folhetim, uma história. São Paulo: Companhia das Letras, 1996.

MICELI, Sérgio. Intelectuais à brasileira. São Paulo: Companhia das Letras, 2001.

NEVES, Margarida de Souza. História da crônica. Crônica da história. In: RESENDE, Beatriz (org.) Cronistas do Rio. Rio de Janeiro: José Olympio, 1994.

O’DONNELL, Júlia. A invenção de Copacabana: culturas urbanas e estilos de vida no Rio de Janeiro. Rio de Janeiro: Jorge Zahar, 2013.

REGO, José Lins do. Fogo morto. Prefácio de Otto Maria Carpeaux. Rio de Janeiro: José Olympio, 1943.

REGO, José Lins do. Meus verdes anos: memórias. 9. ed. Rio de Janeiro: Editora José Olympio, 2011.

REGO, José Lins do. Ligeiros traços: escritos da juventude. Organização de César BragaPinto. Rio de Janeiro: Editora José Olympio, 2007.

RESENDE, Beatriz (org.). Cronistas do Rio. Rio de Janeiro: José Olympio, 1994.

RODRIGUES, Antonio Edmilson Martins; OAKIM, Juliana. As reformas urbanas na cidade do Rio de Janeiro: uma história de contrastes. Acervo, Rio de Janeiro, v. 28, n. 1, 
jan./jun. 2015, p. 19-53. Disponível em: http://revista.arquivonacional.gov.br/index.php/ revistaacervo/article/view/589. Acesso em: 19 nov. 2018.

SANTIAGO, Silviano. Em liberdade: ficçáo. Rio de Janeiro: Paz e Terra, 1981.

SANTINI, Juliana. Entre o riso e a ruína: humor, romance e regionalismo em José Lins do Rego. Teresa - revista de literatura brasileira, São Paulo, n. 16, 2015, p. 175-190. Disponível em: http://www.revistas.usp.br/teresa/article/view/115423. Acesso em: 19 nov. 2018.

SEVCENKO, Nicolau. Literatura como missão: tensôes sociais e criação cultural na Primeira República. São Paulo: Companhia das Letras, 2003.

SICILIANO, Tatiana Oliveira. O Rio de Janeiro de Arthur Azevedo: cenas de um teatro urbano. Rio de Janeiro: Mauad, 2014.

SODRÉ, Nelson Werneck. História da imprensa no Brasil. Rio de Janeiro: Mauad Editora, 1999.

SORÁ, Gustavo. Brasilianas: José Olympio e a gênese do mercado editorial brasileiro. Sáo Paulo: Editora da Universidade de São Paulo/Com-Arte, 2010.

VELLOSO, Mônica Pimenta. Os intelectuais e a política cultural do Estado Novo. Revista de Sociologia e Politica, n. 9, 1997, p. 57-74. Disponível em: https://revistas.ufpr.br/rsp/ article/view/39298. Acesso em: 19 nov. 2018.

VONK, Arthur Vergueiro. A vida ao rés-do-chão, sem chão: Drummond e a moderna crônica brasileira. Dissertação (Mestrado em Letras), Universidade de São Paulo, São Paulo, 2013. Disponível em: http://www.teses.usp.br/teses/disponiveis/8/8151/tde-02072013-110750/ pt-br.php. Acesso em: 19 nov. 2018. 